Global Conferences Series:

Sciences and Technology (GCSST), Volume 3, 2020

The $1^{\text {st }}$ International Conference on Education, Sciences and Technology

DOI: https://doi.org/10.32698/tech3227

\title{
Strengthening Lecturer Resources Model; the Efforts to Improve the Reputation of Universities in the Disruptive Era
}

\author{
Kardoyo, Ida Zulaeha, Ahmad Nurkhin, Muhsin \\ Universitas Negeri Semarang, Indonesia, 50229 \\ kardoyo@mail.unnes.ac.id
}

\begin{abstract}
The challenges of lecturers in the disruptive era are very high. Lecturers are faced with the development of information technology and ethical actions. This study aims to develop a model of strengthening lecturer resources that should be carried out by UNNES. Respondents in this study were lecturers to reveal three variables, namely education, training, and development; performance assessment; and management of lecturer careers. The method of data collection is a questionnaire. The data analysis method used is descriptive analysis and focus group discussion (FGD). The model of strengthening lecturer resources in the disruptive era has been successfully developed. The characteristics of lecturers in the disruptive era are (1) religious and ethical behavior; (2) qualified doctoral studies in reputable domestic or foreign universities; (3) productive in writing scientific works (articles and books); and (4) information technology literacy. The results show that the lecturers strongly agree that there is assistance for lecturers who are pursuing further doctoral studies both domestically and abroad. The lecturer considers it important training that is able to increase innovation in information technology-based learning and the ability to produce quality research proposals. The lecturer considers it important training that is able to increase innovation in information technologybased learning and the ability to produce quality research proposals. Lecturers strongly agree that ethical behavior can be applied properly. The novelty of this research is to develop an original model of strengthening HR lecturers based on need analysis to face the 4.0 industrial revolution.
\end{abstract}

Keywords.disruptive era, lecturer, human resources strengthening

\section{Introduction}

The first cultural revolution of mankind was declared to have occurred during the pre-literacy period of the Neolithic period, when there was a change in human life from a food gathering to food producing. The second revolution occurred during the industrial revolution, when there was a cultural change from manual culture to machinery. The third revolution occurred when there was a change in culture towards the era of information technology. The fourth cultural revolution occurred in the decade of 2010 when humans were faced with innovations as a result of the increasingly high development of information and communication technology in society. This era is called the disruptive era.

Copyright (C) 2019, the Authors. Published by Redwhite Press. 
The disruptive era is often expressed as "VUCA" era, as it stands for "volatility", "uncertainty", "complexity", and "ambiguity". In this era, the role of lecturers experienced a shift. Now, students can have more information than lecturers because access to information sources is already widely available. Lecturers are not the only main source of information. On the other hand, students must also be prepared to face the era of disruptive technology. In the future they must have a work ethic, an open attitude, and be able to work together to solve problems that are increasingly complex and changing rapidly.

UniversitasNegeri Semarang has compiled various policies regarding the development of lecturer resources so that they become qualified and contribute to the success of the policies of the Ministry of Research, Technology and Higher Education. Some of the policies carried out were further study of the lecturers towards the doctoral level, the acceleration of doctors to professors, the increase in publications in reputed international journals, and several policies that led to the achievement of reputation of UNNES in the year of internationalization. The policy needs to be assessed in relation to developments in this disruptive era so that it can be a synergy and reinforcement for the direction of UNNES lecturers' resource development.

Based on the background of the problem, the purpose of this study is to explain the model for developing lecturer resource strengthening conducted by UNNES. This research provides benefits for policy makers at UNNES, in connection with taking policies to upgrade models that have been developed in the disruptive era.

The novelty of this research is to develop an original model of strengthening HR lecturers based on need analysis to face the 4.0 industrial revolution. Lecturers will face very difficult challenges in order to be able to adapt to the development of information technology. Therefore, it needs to be understood about the characteristics of future lecturers. Lecturers will prepare early to continue to develop competencies and expertise in their fields and as needed.

\section{Literature Review}

Research on human resource development has been carried out quite a lot by previous researchers. However, the study of strengthening lecturer resources specifically is quite rare. This research is supposed to develop a model of strengthening lecturer resources, case studies at Semarang State University.

The involvement of lecturers in campus decision making would have a positive and significant effect on the performance of lecturers[1]. Lecturer competence in managing classes will affect the performance of lecturers. Therefore, increasing the competence of lecturers is one of the efforts to guarantee the quality of education in higher education[2].The challenges of lecturers in terms of applying the KKNI-based curriculum[3]. The curriculum is considered able to influence the behavior of lecturers to act professionally. Lecturers will try to apply the curriculum well in lecturing.

There isan evidence that personality, organizational commitment, and job satisfaction can significantly influence lecturer performance. And organizational citizenship behavior is the moderator of all three independent variables [4]. Other result show a positive and significant influence of organizational culture, work environment and job satisfaction on the performance of lecturers[5]. Organizational commitment and motivation have a positive and significant effect on the performance of lecturers[6]. And other researcher examined student involvement in assessing lecturer performance[7].

The improvement of lecturers' performance can be done with various efforts. Lecturers' performance assessment is an effort to analyze the performance of lecturers. Assessment can be carried out periodically and openly. Lecturers' performance assessment will be very relevant if the lecturer has 
obtained systematic strengthening from the university. The strengthening can be in the form of facilitation of further study, the implementation of workshops or training, and self-development activities. Therefore, there is a significant relationship between efforts to strengthen lecturers and performance assessment. The system is integrated into the management of lecturer careers.

\section{Method}

\subsection{Research Design and Procedure}

This research is developmental research within the scope of policy. Referring to the study of the existing Lecturer HR development model, then the identification of the needs of lecturers' performance in the disruptive era is carried out within the scope of Tridharma (Teaching, Research, Community Service) of Higher Education. This research was carried out with the following procedures: (a) Analysis of the current UNNES Lecturer Development Policy Model, (b) Study of Lecturer Performance and Competence Needs from the Tridharma Aspect, (c) Development of the Lecturer Development Conceptual Model, (d) Model Validation, and (e) Formulation of the Policy Plan based on the Valid Model.

\subsection{Techniques of Collecting and Analyzing Data}

Data collection is carried out with two techniques, namely using instruments in the form of questionnaires, chancellor policy documents and regulations, and interviews. Data analysis was carried out by applying descriptive analysis model and focus group discussion (FGD).

\section{Result and Discussion}

\subsection{Research Findings}

This research was conducted in August-October 2018. The research respondents were young lecturers at the UNNES with a maximum lecturer's rank III-b. The research instrument (questionnaire) was distributed to 100 lecturers in all faculties at UNNES. However, only 56 questionnaires were returned and could be processed. The lecturers 'HR strengthening model was developed based on the analysis of lecturers' responses on several variables, including education, training, and development variables, performance assessment variables, and career management variables. Respondents were asked to provide ratings and responses to statement items used for variable measurements.

Table 1 shows some interesting findings on educational indicators. Respondents stated that the disagreement was quite sharp on the two item statements, for instance on the overseas master's degree education item and further study on lecturers who were in structural positions. The respondent's answer score was only 2.75 and 2.64. In addition, respondents also expressed disapproval on Doctoral (S3) Education items that had to go abroad. The score obtained is 3.14. This finding is interesting to be understood by UNNES leaders in taking policies related to the plan for further study of lecturers. S3 study for lecturers who have additional duties (occupying structural positions) is considered to be inappropriate because it will interfere with the completion of studies and the implementation of tasks in certain positions. Obligations for further study in foreign countries for lecturers under the age of 35 years are considered to be heavy obligations.

Table 1. Respondent's Response on Educational Indicator

\begin{tabular}{lll}
\hline No. & Statement & Score \\
\hline 1 & Every lecturer must possess doctoral degree education & 4.20 \\
2 & UNNES provides doctoral study funding & 4.41 \\
3 & It is a must for 32 years old lecturers to produce 2 reputable international journal & 3.71 \\
& articles if they study in domestic universities &
\end{tabular}




\begin{tabular}{lll}
\hline No. & Statement & Score \\
\hline 4 & Every lecturer study doctoral program in foreign countries & 3.14 \\
5 & Minimum education for lecturers is overseas master's degree & 2.75 \\
6 & Lecturers who continue their studies are freed from academic work & 4.29 \\
7 & Providing opportunities to lecturers who continue their studies in domestic & 2.64 \\
& universities to hold structural positions & \\
\hline
\end{tabular}

A very positive response from respondents was seen in item statement regarding funding assistance for lecturers who were studying abroad in a doctoral degree. This is due to a phenomenon that shows the financial difficulties experienced by lecturers while taking further study abroad. The fees needed to complete the study are very high and sometimes the lecturer must find other funding sources from the main source of scholarship. Another item that received a very positive response from respondents was the release of academic duties for lecturers who were studying further. Further study of doctoral program is a tough job especially coupled with the burden of duties and other academic obligations. Therefore, lecturers who are currently taking further study should be freed from the obligation to teaching, thesis advisory, thesis examiner, community service, and other academic obligations.

Table 2 shows the respondent's responses to training indicators. Table 2 shows that there are two training items with the highest score, for instance the importance of learning workshops and workshops for preparing research proposals, the two items obtained the same score of 4.59. The workshop on information technology-based learning is a necessity for lecturers to keep up to date on the latest learning strategies that utilize information technology. Lecturers will be more creative and innovative in managing classes so that they will be able to improve the quality of lectures. Workshop on research proposal preparation is also needed by lecturers to be able to produce quality research and produce published scientific articles in reputable international journals.

Table 2. Respondents' Response on Training Indicator

\begin{tabular}{lll}
\hline No. & Statement & Score \\
\hline 1 & $\begin{array}{l}\text { It is compulsory for every lecturer to have a certificate of PEKERTI } \\
\text { (Instructional Techniques Skill Enhancement Training) and AA (Applied }\end{array}$ & \\
& $\begin{array}{l}\text { Approach) } \\
\text { Every year lecturers attend academic training in accordance with the }\end{array}$ & 4.59 \\
2 & $\begin{array}{l}\text { development of information technology } \\
\text { Research proposal writing workshops are held annually }\end{array}$ & 4.59 \\
3 & Inviting speakers from research funding institutions when researching & 4.43 \\
4 & There is an article writing workshop after conducting research & 4.36 \\
5 & There is a reference book writing workshop after conducting research & 4.29 \\
6 & Lecturers need to have a leadership management training & 4.23 \\
8 & Lecturers need to have character education training & 4.36 \\
\hline
\end{tabular}

Respondents' response on the development indicators are then presented in table 3 below. The results show that the code of ethics items is the most important thing for lecturers. The score obtained is 4.80 highest among the other statement items. The lecturer considers that the code of ethics is an important thing that must be obeyed. UNNES has regulations regarding the lecturer and employee code of ethics and a code of ethics for students. The next item that gets a high score is the opportunity to develop mastery of the field of study. This is very necessary for lecturers to be able to master the competence of the field of study so that they will be able to compete. Lecturers can develop competencies in the field of study in various ways, such as following education and training, seminars, conferences, workshops, focus group discussions, and other scientific meetings. Campus must provide adequate facilities. 
Table 3. Respondents' Response on Development Indicator

\begin{tabular}{lll}
\hline No. & Statement & Score \\
\hline 1 & Provide opportunities for lecturers to develop the field of study mastery & 4.75 \\
2 & UNNES facilitates the improvement of foreign language skills & 4.54 \\
3 & Every lecturer must be well-mannered in social media & 4.59 \\
4 & Lecturer's code of ethics must be obeyed & 4.80 \\
5 & Lecturers must be proficient at management skills & 4.30 \\
6 & Lecturers must be proficient at decision-making skills & 4.35 \\
\hline
\end{tabular}

Performance assessment is the next variable measured in this study. The results of respondents' responses can be seen in table 4. An open and transparent assessment is the expectation of lecturers themselves. This can be seen in the score which is obtained at 4.52 , the highest score among other items. Lecturers must know performance assessment indicators. The lecturer will understand the performance assessment. The lecturer also argued that tri dharma of higher education is an indicator of lecturer assessment. Tri dharma of Higher Education in question is teaching, research, and community service. Assessment of lecturer performance must be based on Tridharma of Higher Education. The interesting thing about the performance assessment variable is that the assessment does not always function as a differentiator for diligent lecturers and indolent lecturers.

Table 4. Respondents' Response on Performance Assessment Variable

\begin{tabular}{lll}
\hline No. & Statement & Score \\
\hline 1 & $\begin{array}{l}\text { Lecturers' performance assessment can be used to examine strengths } \\
\text { weaknesses }\end{array}$ & 4.09 \\
2 & $\begin{array}{l}\text { Lecturer performance assessment functions to distinguish between diligent } \\
\text { and indolent lecturers }\end{array}$ & 3.82 \\
3 & Involving lecturers in planning assessment & 4.20 \\
4 & The assessment plan is prepared by Team & 4.02 \\
5 & Lecturers' performance assessment must be well documented & 3.98 \\
6 & Using information technology in the assessment of lecturers' performance & 4.23 \\
7 & The lecturer knows the assessment indicators openly & 4.52 \\
8 & Tri Dharma of Higher Education is an indicator of lecturer's assessment & 4.46 \\
9 & Students are involved in the assessment of lecturers' performance in class & 4.20 \\
10 & The Head of Department who assesses the performance of lecturers & 3.95 \\
\hline
\end{tabular}

Table 5 shows the responses of respondents regarding career management variables. Lecturers give positive responses to career management variables. Lecturers really need career management in order to be able to give maximum contribution to the Institution through improving their qualifications. The item statement that gets the highest score is the opportunity to apply for a promotion every 2 years. The phenomenon shows that there are a few lecturers who are able to manage their promotion. Difficulties in managing administrative promotion are the main reasons for lecturers. Lecturers become unmotivated because they face a complicated administration and tend to not make it easy. Therefore, it is not surprising if the next item that gets the highest score is the use of a promotion information system. This is very important so that lecturers are not too busy managing the administration of promotions. The existence of an information system is the solution to the lecturer's functional position enhancement. 
Table 5. Respondents' Response on Career Management Variable

\begin{tabular}{|c|c|c|}
\hline No. & Statement & Score \\
\hline 1 & $\begin{array}{l}\text { lecturers are given the opportunity to submit a functional position promotion } \\
\text { every two years }\end{array}$ & 4.68 \\
\hline 2 & The use of IT-based information systems of functional position promotion & 4.55 \\
\hline 3 & $\begin{array}{l}\text { Providing opportunity for doctors to teach in postgraduate programs } \\
\text { according to their competences }\end{array}$ & 4.48 \\
\hline 5 & Reinforcement are given based on the level of mistakes & 4.46 \\
\hline
\end{tabular}

Another interesting result in career management variables is reinforcement for lecturers who violate the code of ethics. It is very reasonable if there are lecturers who disobey the code of ethics must be given fair reinforcement. The institutions leaders must be fair to all lecturers and may not be selective in giving reinforcement. The given reinforcement must also be based on the level of mistakes. Leaders must avoid KKN (corruption, collusion and nepotism) in resolving cases of violations of the code of ethics in order to gain more trust from all academics.

\subsection{Discussion}

The data was analyzed to develop a model of strengthening lecturer resources based on respondents' responses. The analysis was carried out through the implementation of a focus group discussion by inviting HR Management experts, Vice Rector for General and Financial Affairs, Vice Dean for General and Financial Affairs, Vice Director for General and Financial Affairs, HRD bureau, and lecturers.

The FGD functions to analyze the priority of strengthening lecturer resources. According to the Vice Rector for General and Financial Affairs, Dr. S. Martono, lecturers play an important role in organizing education in higher education. Lecturers will face tough challenges in a disruptive era so that lecturers must be able to develop themselves and be able to adapt to the development of information technology. Lecturers are also required to be able to manage careers, so they don't become ordinary lecturers. UNNES conducts routine performance assessment and provides rewards for lecturers' performance. UNNES also provides opportunities for career advancement for lecturers. Information systems are currently being developed that will make it easier for lecturers to manage position promotions.

The results of lecturer resources strengthening model development in the disruptive era can be seen in figure 1 below. The characteristics of lecturers in the disruptive era are (1) religious and behaving ethically; (2) doctoral candidates from reputable domestics or foreign universities; (3) productive in writing articles and books (scientific works); and (4) information technology literacy. The first character reflects lecturers' personal and social strength. This is in accordance with the ideals of the 1945 Constitution where education produces intelligent human beings who have good moral value. The second character is a minimum prerequisite for lecturers in the future in terms of educational background. The lecturer must possess a doctorate degree from a qualified higher education institution. Lecturers must choose a qualified and internationally reputable campus. The third character reflects the productive work of lecturers in writing journal articles and scientific books. The work of lecturers must be original and useful and recorded as intellectual property rights, and the fourth character is a supporting character. Lecturers must literally be accustomed to information technology for the sake of lectures development. It is also beneficial for lecturers when they are able to use and operate information technology, especiallyto facilitate tridharma activities.

Strengthening the resources of lecturers in disruptive era with the characteristics described earlier can be done through training and self-development. The training in question is various forms of training and education to strengthen the competencies that have been possessed by lecturers. The training in question includes training on innovative information technology-based learning, workshops for reputable journal articles writing, workshops for qualified research proposals writing, and other workshops. Lecturers will get sufficient input to improve quality in accordance with the lecturers' 
competence and additional expertise. Lecturers will be able to produce international quality scientific works (research, books, articles).

Information system-based performance assessment is needed to implement a fair and transparent assessment system. Lecturers will be assessed regularly (yearly) based on Tri Dharma activities they have done. Performance assessment should also be based on information systems to make it easier and able to work accurately. Performance assessment is carried out to determine reward to be received by lecturers in accordance with the performance of each.

The final aspect of lecturer resource strengthening model in Figure 1 is the management of lecturers' careers. Lecturers' good performance must be assessed fairly and they should be given desirable reward afterwards. The process of strengthening lecturer resources through training and selfdevelopment accompanied by performance assessment will bring about lecturers' careers management. Lecturers will be then motivated to manage their career by looking at policies that can increase their productivity. Fair and transparent performance assessment will further enhance the work motivation of lecturers. He will be more productive because he is assessed and will get a desirable reward.

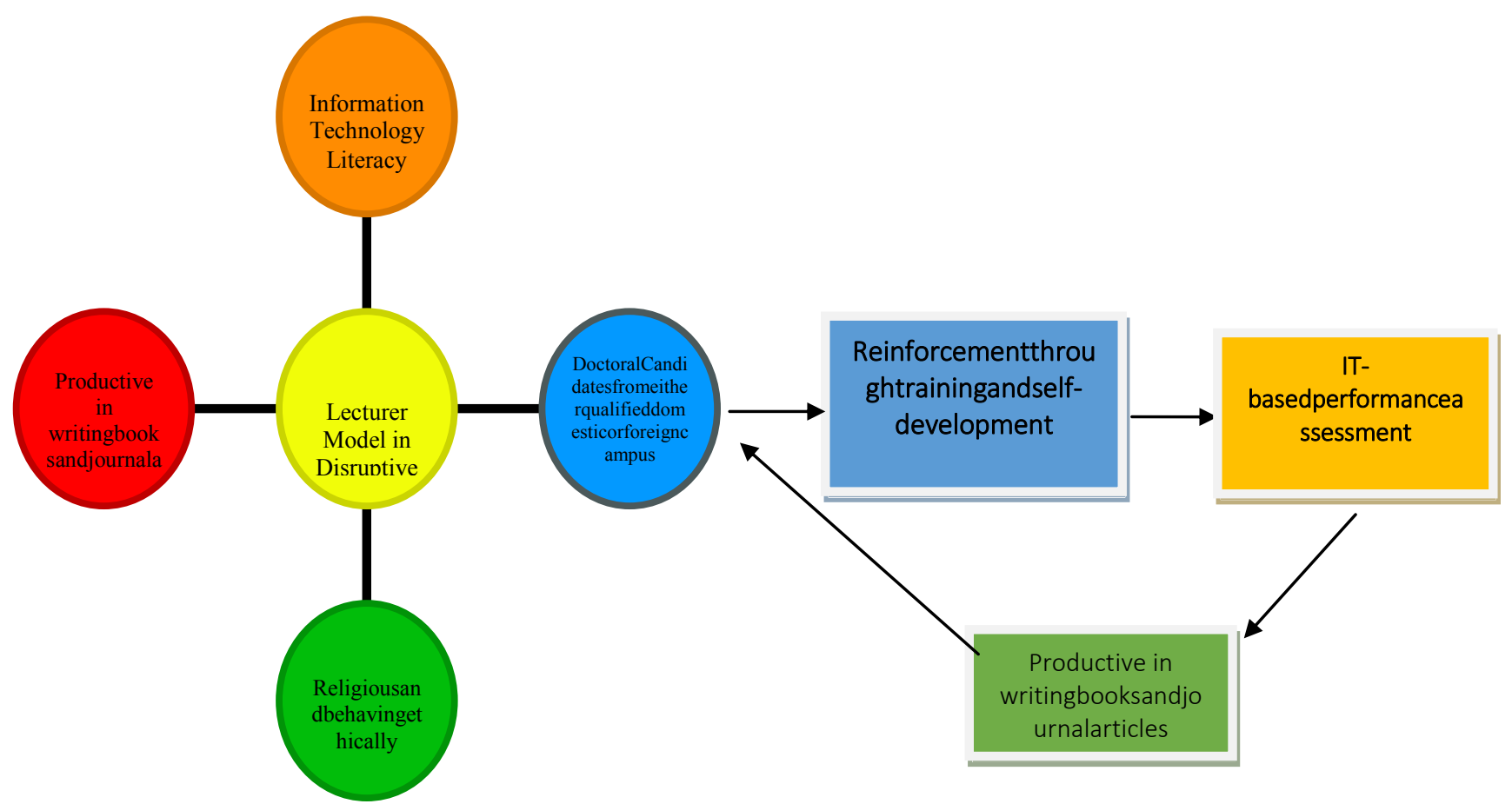

Figure 1. Model for Lecturer Resources Strengthening in Disruptive Era

\section{CONCLUSION}

The results of the study showed that the responses to the education indicators showed that the lecturers strongly agreed that there was assistance for lecturers who were undertaking further doctoral studies both domestically and abroad.Lecturers who are continuing further studies should be set free from campus academic duties. The next results show that lecturers strongly agree that lecturers should behave ethically according to existing regulations. Lecturers must be able to uphold rules and ethics and comply with the regulations. The assessment of lecturers' performance must be transparent and fair as well as utilizing information technology. Conducting reinforcement or sanction against lecturers must also be in accordance with the assessment of mistakes made. Career management must get approval from the lecturer themselves for academic position promotions regularly. 
The model of strengthening lecturer resources in disruptive era has been successfully developed. The characteristics of lecturers in disruptive era are (1) religious and behaving ethically; (2) qualified doctoral studies in reputable domestic or foreign universities; (3) productive in writing articles and books (scientific works); and (4) information technology literacy.

\section{References}

[1] D. S. Sukirno and S. Siengthai, "Does participative decision making affect lecturer performance in higher education?," Int. J. Educ. Manag., vol. 25, no. 5, pp. 494-508, 2011.

[2] R. D. Anggraeni, "Increasing Lecturer Competence as the Quality Assurance of Lecturer Performance," Manag. Stud., vol. 2, no. 5, pp. 309-329, 2014.

[3] Khalsiah, N. Asma, and Marina, "The Efforts of Improving the Professionalism of Lecturers towards the Presentation and Change of KKNI within the University Environment in Aceh," in MICoMS 2017, 2018, pp. 19-25.

[4] W. Hakim and A. Fernandes, "Moderation effect of organizational citizenship behavior on the performance of lecturers," J. Organ. Chang. Manag., vol. 30, no. 7, pp. 1136-1148, 2017.

[5] M. Awaluddin, "Penguatan Peran Lingkungan Kerja dan Budaya Organisasi dalam Mengoptimalkan Kinerja Dosen Universitas Islam Negeri Alauddin Makassar melalui Kepuasan Kerja,” J. Manajemen, Ide, Inspirasi, vol. 5, no. 1, pp. 53-67, 2018.

[6] M. D. Dinantara, "The Influence Of Organizational Commitment And Motivation On Lecturer Performance Of Pamulang University," Sci. J. Reflect. Econ. Accounting, Manag. Bussines, vol. 1, no. 3, pp. 71-80, 2018.

[7] H. Gul, "Evaluation of Lecturer Performance Depending on Student Perception in Higher Education," Educ. Sci., vol. 35, no. 158, pp. 158-168, 2010. 